\title{
発育期の運動と糖尿病 〜モデル動物を用いた検討〜
}

\author{
都 築 孝 允, 内藤 久士 \\ (順天堂大学大学院スポーツ健康科学研究科運動生理学研究室)
}

【要約】現在, 生活習慣病は大人のみならず子どもにお いても増加しており大きな社会問題となっている.一方, 生涯の健康, 特に生活習慣病の予防に対して発育期の運 動や身体活動がどのような影響を与えるかについてはほ とんど明らかにされていない. そこで, 我々が 2 型糖尿 病のモデル動物であるOLETFラットを用いて, 現在取 り組んでいる研究を紹介した.

2 型糖尿病を含め, 生活習慣病の罹患率は大人のみな らず子どもに扔いても増加しており，早急に対策しなけ ればならない社会問題となっている. 生活習慣病の予防・ 改善に対して運動が効果的であるということは多くの研 究によって明らかにされてきた。しかしながら, これら の研究の対象は主にリスクファクターを有する中高齢者 や疾患患者であり, 子どもを対象とした基礎的掞よび応 用的研究は立ち後れているのが現状である。 また, 生活 習慣病の予防という視点に立つと, 生涯の健康に対して 発育期の運動や身体活動がどのような影響を与えるのか についてはほとんど明らかにされておらず，特に実験的 なエビデンスの蓄積は不十分である。このような視点で の研究が進まない原因の一つとして, 運動の影響を超長 期的に観察しなければならないため, ヒトを対象とした 研究は非常に困難である。 そこで, 我々は生活習慣病の 中でも 2 型糖尿病に着目をし， 2 型糖尿病のモデル動物 である Otsuka Long-Evans Tokushima Fatty (OLETF) ラットを用いて研究を行っている。発育期の運動がその 後の健康に与える影響, 特に 2 型糖尿病の発症予防に与 える影響を明らかにするために我々が現在取り組んでい る研究について紹介した。

雄性の OLETFラットは, 幼少期から過食により肥満 を呈し，抢よそ25週齢でほぼ全ての個体が糖尿病を発症 するが，このOLETFラットに対して 5 ２5週齢まで回 転ホイールを用いた自発運動を行わせところ, 体重増加
の抑制，安静時代謝の低下抑制，耐糖能の維持および血 中脂質の増加抑制が観察された。一方，発育期を含む 5 〜15週齢まで自発運動を行わせ，その後15２5週齢まで 安静に戻したところ, 運動中止後すぐに体重が増加し始 め, 耐糖能も悪化し始めた。 しかしながら, 安静時代謝 の低下および血中トリグリセライドの増加は抑えられて おり, 発育期の運動の効果には比較的早期に消失するも のと維持されるものとがあった，現在，これらの結果を 説明するために，発育期を含む運動掞よび運動の中止が 2 型糖尿病ラットにどのような影響を与えるかについ て, 臓器別に検討を加えている。これらの結果は, 生涯 を通した健康の維持に対する発育期の運動の重要性を示 す科学的なエビデンスになるかもしれない.

以上, 発育期の運動がその後の健康に与える影響につ いて, 我々が現在取り組んでいる研究成果を紹介した。 今後, 様々な観点から子どもを対象にした研究の進展と エビデンスの蓄積を期待したい。 また，運動により得ら れる有益な影響が遺伝するかなど, 子どもの健康に与え る遺伝的な影響についても, 今後検討していくべき重要 な課題であると考えている.

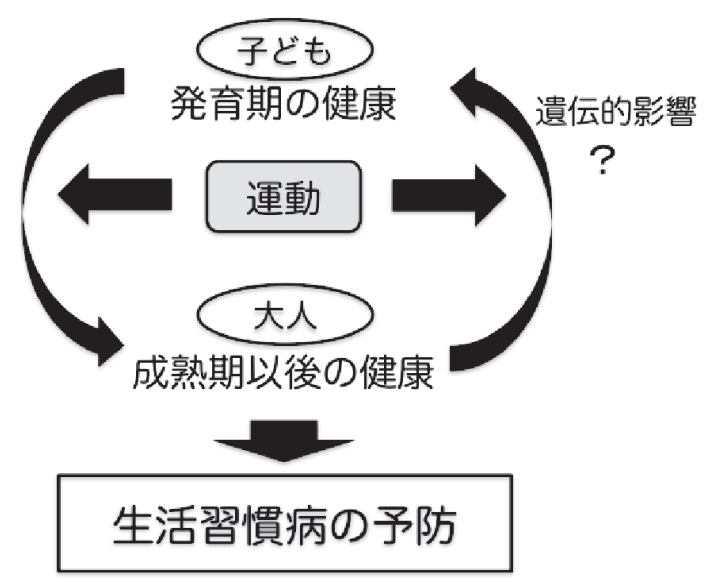

